\title{
Association of Truancy and Health Risk Behaviours among School-Going Adolescents in Malaysia
}

\author{
Nur Azna Mahmud, S. Maria Awaluddin, Norzawati Yoep, Wan Shakira Rodzlan Hasani, \\ Jane Ling Miaw Yn, Lim Kuang Kuay
}

Institutes for Public Health, National Institutes of Health Malaysia, Selangor, Malaysia

Email: aznanur@yahoo.com

How to cite this paper: Mahmud, N.A., Awaluddin, S.M., Yoep, N., Hasani, W.S.R., Yn, J.L.M. and Kuay, L.K. (2019) Association of Truancy and Health Risk Behaviours among School-Going Adolescents in Malaysia. Open Journal of Social Sciences, 7, 228-237.

https://doi.org/10.4236/jss.2019.77021

Received: May 29, 2019

Accepted: July 23, 2019

Published: July 26, 2019

Copyright $\odot 2019$ by author(s) and Scientific Research Publishing Inc. This work is licensed under the Creative Commons Attribution-NonCommercial International License (CC BY-NC 4.0). http://creativecommons.org/licenses/by-nc/4.0/

\section{Open Access}

\begin{abstract}
Truancy may act as a precursor or a consequence of many behavioural problems that might have potentially deleterious effects. This study examined factors associated with truancy among 27,497 school-going adolescents. Data were obtained from the National Health and Morbidity Survey 2017, a cross-sectional survey which targeted Malaysian school-going adolescents aged 13 to 17 years. A two-stage stratified cluster sampling was applied and data collection was conducted using validated self-administered questionnaire. Descriptive and multiple variables' logistic regression analysis was applied and $\mathrm{p}$ value $<0.05$ was considered as a statistically significant result. Overall prevalence of truancy among school-going adolescents in Malaysia was $29.4 \%(27.78,31.06)$. Truancy among Malaysian adolescent is associated with ever drug user $[\mathrm{AOR}=2.51 ; 95 \% \mathrm{CI}:(2.18,2.90)]$, current cigarette smoker $[\mathrm{AOR}=2.02 ; 95 \% \mathrm{CI}:(1.86,2.19)]$, other ethnicity $[\mathrm{AOR}=1.41 ; 95 \%$ CI: $(1.18,1.68)]$, adolescent's parents who live apart $[\mathrm{AOR}=1.38$; $95 \% \mathrm{CI}$ : $(1.28,1.47)]$, being bullied $[\mathrm{AOR}=1.37 ; 95 \%-\mathrm{CI}=(1.28,1.47)]$, older aged $[\mathrm{AOR}=1.37 ; 95 \% \mathrm{CI}:(1.30,1.45)]$ and male $[\mathrm{AOR}=1.09 ; 95 \% \mathrm{CI}:(1.03$, 1.15)]. Truancy has been associated with various health risk behaviours that may influence its development and adulthood health status. Investigation on the true cause of truancy among adolescent may highlight the underlying problems and plan for further intervention.
\end{abstract}

\section{Keywords}

Associated Factor, Malaysia, School-Going Adolescent, Truancy

\section{Introduction}

Truancy among school-going adolescents remains an unsolved issue for many 
years faced by education system globally. Increasing trends in truancy cases have drawn the attention not only from the educators and family, but also the public, since truant behaviour may lead to juvenile delinquency [1] [2]. In Malaysia, despite an increasing number of truancy cases and abundance of preventions taken to overcome this issue, truancy continues to exist as the number one discipline problem with 1.4 percent equivalent to 67,053 students from approximately five million of primary and secondary student all over Malaysia according to Ministry of Education records in 2017. Truancy was found to be the highest among secondary school students in Malaysia, and the second highest among eight types of discipline misbehaviour listed by Ministry of Education [3] [4]. Studies carried out in Malaysia show that the rate of student playing truant ranges from $20 \%$ to $40 \%$. [3] [5].

Truancy is a psychiatric implication where it is a way for adolescents to express their feeling in dealing with school failures [6] [7]. It is also a self-esteem's interaction of the adolescent and peer pressure reflex [8]. Poor school engagement and less parental involvement may also lead to low grades and might turn to be the determinants of truancy [9]. Emphasizing on punishment instead of reward by some of the school systems might worsen truancy and reduce motivation of the student to go to the school [10]. A lot of studies focus on truancy as the determinants of the misbehaviour, which overlooked the potential factors contributing to truancy. Misbehaviour such as smoking, illicit drug misuse, alcohol, violence and bully has shown to be the contributing factor of truancy [11] [12]. A study in the United State reported that, being bullied in school has a strong association with risk of frequently absent [13]. This indicates that preventing the negative behaviour among school-going adolescent in school is vital in reducing truancy cases. Focusing on the positive behaviour of the youth and increasing school involvement in motivating them towards academic and life skills will reduce negative behaviour and promote optimal positive growth of the school going adolescent [14]. Therefore, this study aimed to identify the prevalence and associated factor of truancy among Malaysian adolescents aged 13 to 17 years old and give an overview on different perspectives in reducing truancy.

\section{Methodology}

\subsection{Sampling Design}

This cross-sectional, school-based study used two-stage stratified sampling design according to the national school frame to ensure national representativeness. Target population in the National Health Morbidity Survey 2017: Adolescent Health (NHMS 2017) was all school going adolescent aged 13 to 17 years old in randomly selected secondary schools. Students with mental retardation and from special education class were excluded from the survey.

\subsection{Data Collection}

A structured and validated questionnaire developed by WHO and the Centers 
for Disease Control and Prevention (CDC) in collaboration with UNICEF, UNESCO, and UNAIDS in 2001 is used in the survey [15]. Local adaptation and validation of the questionnaire was performed before the data collection phase [16]. This study was conducted in the school where school-going adolescent completed self-administered questionnaires upon giving their consents. For accessing truant behavior, school-going adolescent were asked "During the past 30 days, on how many days did you miss classes or school without permission". Those who answer miss classes for 1 to 30 days were considered playing truant.

\subsection{Statistical Analysis}

Statistical Package for Social Science (SPSS) version 20 software was used for data analysis [17]. Descriptive and summary statistic was carried out for the prevalence of truancy among the school-going adolescent. Bivariate/multivariate logistic regression analyses were used to determine the associated factors of truancy among school going adolescents in Malaysia. Association between truancy with socio-demographic characteristic, ever drug use, current cigarette smoking and being bullied were analysed using bivariate analysis. Crude odds ratio was used to measure the single association of dependent and independent variables. While for factors associated with truancy, multivariable logistic regression model was applied by including the independent variables. Significant variables with $p$-value less than 0.25 , was counted into the final model. The adjusted OR was calculated with $p$-value less than 0.05 was considered significant.

\subsection{Variable Definition}

Truancy was defined as missing at least one day of class or school without permission in the past 30 days. Locality was categorized as urban and rural based on Department of Statistical Malaysia. Respondents were divided into two groups: 13 - 15 years old $(n=8229)$ and 16 - 17 years old $(n=4906)$. For ethnicity, Bumiputera Sabah and Bumiputera Sarawak refer to Sabahan and Sarawakian respectively. Others are those who do not belong to the above ethnic groups including aborigines (orang asli and foreigners) Marital status of parent was categorised into living together and living apart. Ever drug user was defined as school-going adolescents who had history of drug use in their lifetime. Current cigarette smoker refers to school going adolescent who smoked manufactured cigarette, rolled-your-own, or traditional hand roll cigarette in the past 30 days. While for being bullied, was referred to when a student or group of students were being attacked by other students in the past 30 days.

This survey was reviewed and approved by the Medical Research and Ethics Committee, Ministry of Health, Malaysia. All respondents were given an information sheet and a copy of signed consent form. For those who were illiterate, the information sheet and consent form were read to them and their thumb prints were taken in lieu of signatures. 


\section{Results}

Overall response rate for this survey was $89.2 \%$ involving school going adolescent aged 13 to 17 years old. From 27,497 school going adolescents involved in this survey, 13,135 (49.6\%) were male and 14,362 (50.4\%) were female. In terms of ethnicity, $63.1 \%$ were Malays decent, followed by $16.7 \%$ Chinese decent, $7.0 \%$ Indian decent, 7.0\% Bumiputera Sabah decent, $4.5 \%$ Bumiputera Sarawak and $1.8 \%$ Others. More than half of the schools going adolescent were those of younger age group. (60.7\%) (Table 1). A total of 27,497 schools going adolescent responded to the truancy module. Among them, 7985 (29.4\%) were found to play truant. High prevalence was found in male, old age, others ethnicity, parents living apart, ever drug user, current cigarette smoker and being bullied (Table 2). Univariate analysis showed significant association between truancy and socio demographic characteristic as well as other variables; ever drug user, current cigarette smoker and being bullied. Multivariate analysis showed determinants of truancy found to be male, old age, others ethnicity, parents living apart, ever drug user, current cigarette smoker and being bullied after controlling with other variables. Adjusted odd ratio values of these determinants were tabulate in Table 3.

\section{Discussions}

Overall prevalence of truancy among school going adolescent in Malaysia for 2017 was $29.4 \%$ which is comparable with previous studies conducted in Malaysia; $30.8 \%$ [18], $30.4 \%$ [3], and $34.4 \%$ [19]. These findings were found to be higher than other countries; $20.4 \%$ in Thailand [20], 21.6\% in Swaziland [21] and $11 \%$ in the United State [9]. The gap of findings might be due to differences in definition of truancy, different study design or method and nature of lifestyle and culture in each country.

Many studies found that, male adolescent were prone to play truant compare to female [3] [22] and [23]. A study done in Japan, [21] stated that cultural expectation might be the reason why male adolescent were more likely to be truant than female. Another study, [24] reported that there is significant difference of perception on causes of truancy among male and female adolescent. However, we also found few studies stated that gender difference did not influence truant behaviour and the prevalence of truancy among the gender show no significant different [18] [25] and [26].

Among age group, older age group adolescent (15 to 17 years old) shows higher prevalence, $32.8 \%$ and were 1.36 odd to truant compare to younger age group (13 to 14 years old). Truant behaviour increase parallel with adolescent age [3]. These might be due to younger age adolescent are protected from truant behaviour due to strictly supervised by the parent. In terms of ethnicity, our finding are in accordance with previous studies [27]. [28] and [29] showing that prevalence of truancy varies among ethnicity and ethnic minority groups show higher prevalence and were likely to play truant compare to adolescent from ethnic majority groups. 
Table 1. Distribution of School going adolescent by socio demographic profile $(n=27,497)$.

\begin{tabular}{|c|c|c|c|c|c|c|c|c|c|c|c|}
\hline & \multirow{3}{*}{ Variables } & \multicolumn{5}{|c|}{ Male } & \multicolumn{5}{|c|}{ Female } \\
\hline & & \multirow[b]{2}{*}{$\mathrm{N}$} & \multicolumn{4}{|c|}{$95 \% \mathrm{CI}$} & \multirow[b]{2}{*}{$\mathrm{N}$} & \multirow[b]{2}{*}{$\mathrm{n}$} & \multirow[b]{2}{*}{$\%$} & \multicolumn{2}{|c|}{$95 \% \mathrm{CI}$} \\
\hline & & & $\mathrm{n}$ & $\%$ & Lower & Upper & & & & Lower & Upper \\
\hline & Malaysia & $1,064,953$ & 13,135 & 49.6 & 46.38 & 52.85 & $1,081,492$ & 14,362 & 50.4 & 47.15 & 53.62 \\
\hline \multirow[t]{2}{*}{ Age } & $\begin{array}{c}\text { Young } \\
(13-15)\end{array}$ & 655,718 & 8229 & 30.5 & 28.42 & 32.77 & 646,780 & 8723 & 30.1 & 27.97 & 32.39 \\
\hline & $\begin{array}{c}\text { Old } \\
(16-17)\end{array}$ & 409,234 & 4906 & 19.1 & 17.13 & 21.17 & 434,712 & 5639 & 20.25 & 18.23 & 22.44 \\
\hline \multirow[t]{6}{*}{ Ethnicity } & Malay & 667,495 & 8861 & 49.3 & 46.04 & 52.52 & 687,043 & 9852 & 50.7 & 47.48 & 53.96 \\
\hline & Chinese & 182,840 & 2056 & 51.0 & 45.23 & 56.75 & 175,664 & 2044 & 49.0 & 43.25 & 54.77 \\
\hline & Indian & 74,103 & 645 & 49.7 & 35.79 & 63.58 & 75,124 & 783 & 50.3 & 36.42 & 64.21 \\
\hline & Bumiputera Sabah & 72,262 & 833 & 48.4 & 45.46 & 51.31 & 77,091 & 948 & 51.6 & 48.69 & 54.54 \\
\hline & Bumiputera Sarawak & 49,746 & 481 & 51.4 & 44.44 & 58.26 & 47,077 & 440 & 48.6 & 41.74 & 55.56 \\
\hline & Others & 18,505 & 259 & 48.7 & 41.99 & 55.46 & 19,491 & 295 & 51.3 & 44.54 & 58.01 \\
\hline Marital & Living together & 878,224 & 10,833 & 49.9 & 46.60 & 53.13 & 882,894 & 11,796 & 50.1 & 46.87 & 53.40 \\
\hline $\begin{array}{l}\text { Status of } \\
\text { Parents }\end{array}$ & Living apart & 157,028 & 1946 & 46.5 & 42.87 & 50.12 & 180,850 & 2356 & 53.5 & 49.88 & 57.13 \\
\hline
\end{tabular}

Table 2. Distribution of School going adolescent by socio demographic profile $(n=27,497)$.

\begin{tabular}{|c|c|c|c|c|c|c|c|c|c|c|c|}
\hline & \multirow{3}{*}{ Variables } & \multicolumn{5}{|c|}{ Yes } & \multicolumn{5}{|c|}{ No } \\
\hline & & \multirow[b]{2}{*}{$\mathrm{N}$} & \multirow[b]{2}{*}{$\mathrm{n}$} & \multicolumn{3}{|c|}{$95 \%$ CI } & \multirow[b]{2}{*}{$\mathrm{N}$} & \multirow[b]{2}{*}{$\mathrm{n}$} & \multirow[b]{2}{*}{$\%$} & \multicolumn{2}{|c|}{$95 \%$ CI } \\
\hline & & & & $\%$ & Lower & Upper & & & & Lower & Upper \\
\hline & Malaysia & 630,100 & 7985 & 29.4 & 27.78 & 31.06 & $1,513,571$ & 19,477 & 70.6 & 68.94 & 72.22 \\
\hline \multirow{2}{*}{ Gender } & Male & 346,690 & 4188 & 32.6 & 30.61 & 34.65 & 716,848 & 8927 & 67.4 & 65.35 & 69.39 \\
\hline & Female & 283,410 & 3797 & 26.2 & 24.46 & 28.10 & 796,722 & 10,550 & 73.8 & 71.90 & 75.54 \\
\hline \multirow[t]{2}{*}{ Age } & Young & 353,275 & 4568 & 27.2 & 25.35 & 29.04 & 947,591 & 12,364 & 72.8 & 70.96 & 74.65 \\
\hline & Old & 276,825 & 3417 & 32.8 & 30.36 & 35.43 & 565,979 & 7113 & 67.2 & 64.57 & 69.64 \\
\hline \multirow[t]{5}{*}{ Ethnicity } & Malay & 394,237 & 5455 & 29.1 & 27.51 & 30.81 & 959,080 & 13,241 & 70.9 & 69.19 & 72.49 \\
\hline & Chinese & 99,325 & 1068 & 27.7 & 24.12 & 31.69 & 258,630 & 3024 & 72.3 & 68.31 & 75.88 \\
\hline & Bumiputera Sabah & 51,635 & 577 & 34.6 & 26.93 & 43.11 & 97,707 & 1200 & 65.4 & 56.89 & 73.07 \\
\hline & Bumiputera Sarawak & 22,566 & 226 & 23.3 & 19.50 & 27.66 & 74,144 & 694 & 76.7 & 72.34 & 80.50 \\
\hline & Others & 14,055 & 212 & 37.2 & 31.84 & 42.82 & 23,763 & 341 & 62.8 & 57.18 & 68.16 \\
\hline \multirow{2}{*}{$\begin{array}{c}\text { Marital Status } \\
\text { of Parent }\end{array}$} & Living together & 490,903 & 6228 & 27.9 & 26.21 & 29.67 & $1,268,304$ & 16,376 & 72.1 & 70.33 & 73.79 \\
\hline & Living apart & 121,484 & 1534 & 36.0 & 34.00 & 38.14 & 215,530 & 2758 & 64.0 & 61.86 & 66.00 \\
\hline Ever & Yes & 54,200 & 620 & 59.1 & 54.99 & 63.12 & 37,483 & 392 & 40.9 & 36.88 & 45.01 \\
\hline Drug User & No & 575,900 & 7365 & 28.1 & 26.51 & 29.68 & $1,475,792$ & 19,081 & 71.9 & 70.32 & 73.49 \\
\hline $\begin{array}{l}\text { Current } \\
\text { cigarette }\end{array}$ & Yes & 145,379 & 1726 & 49.3 & 46.54 & 52.11 & 149,377 & 1861 & 50.7 & 47.89 & 53.46 \\
\hline Smoker & No & 484,721 & 6259 & 26.2 & 24.67 & 27.83 & $1,363,974$ & 17,613 & 73.8 & 72.17 & 75.33 \\
\hline Bullied & No & 495,616 & 6304 & 27.6 & 26.06 & 29.24 & $1,298,728$ & 16,699 & 72.4 & 70.76 & 73.94 \\
\hline
\end{tabular}


Table 3. Factors associated with truancy among school going adolescent using Multiple Logistic Regression $(n=27,462)$.

\begin{tabular}{|c|c|c|c|c|c|c|}
\hline \multirow[b]{2}{*}{ Truancy } & \multicolumn{3}{|c|}{ Simple Logistic Regression (SLR) } & \multicolumn{3}{|c|}{ Multiple Logistic regression (MLR) } \\
\hline & $b$ & $\begin{array}{l}\text { Crude OR } \\
(95 \% \mathrm{CI})\end{array}$ & $p$-Value & $b$ & $\begin{array}{l}\text { Adjusted OR* } \\
\quad(95 \% \mathrm{CI})\end{array}$ & $p$-Value \\
\hline \multicolumn{7}{|l|}{$\operatorname{Sex}$} \\
\hline Male & 0.27 & $1.34(1.24,1.37)$ & $<0.001$ & 0.09 & $1.09(1.03,1.15)$ & 0.002 \\
\hline Female & 0 & 1 & - & 0 & 1 & - \\
\hline \multicolumn{7}{|l|}{ Age } \\
\hline Young & 0 & 1 & - & 0 & 1 & - \\
\hline Old & 0.26 & $1.30(1.23,1.37)$ & $<0.001$ & 0.31 & $1.37(1.30,1.45)$ & $<0.001$ \\
\hline \multicolumn{7}{|l|}{ Ethnicity } \\
\hline Malay & 0 & 1 & - & 0 & 1 & - \\
\hline Chinese & -0.15 & $0.86(0.79,0.93)$ & $<0.001$ & -0.14 & $0.87(0.80,0.94)$ & $<0.001$ \\
\hline Indian & 0.11 & $1.11(0.99,1.25)$ & 0.077 & 0.03 & $1.03(0.91,1.16)$ & 0.665 \\
\hline Bumiputera Sabah & 0.16 & $1.17(1.05,1.30)$ & 0.004 & 0.07 & $1.08(1.0,1.20)$ & 0.184 \\
\hline Bumiputera Sarawak & -0.24 & $0.79(0.68,0.92)$ & 0.003 & -0.37 & $0.69(0.60,0.81)$ & $<0.001$ \\
\hline Others & 0.41 & $1.51(1.27,1.80)$ & $<0.001$ & 0.34 & $1.41(1.18,1.68)$ & $<0.001$ \\
\hline \multicolumn{7}{|l|}{ Marital Status } \\
\hline Living together & 0 & 1 & - & 0 & 1 & - \\
\hline Living apart & 0.40 & $1.49(1.39,1.9)$ & $<0.001$ & 0.32 & $1.38(1.28,1.47)$ & $<0.001$ \\
\hline \multicolumn{7}{|l|}{ Ever illicit drug user } \\
\hline Yes & 1.41 & $4.10(3.60,4.66)$ & $<0.001$ & 0.92 & $2.51(2.18,1.47)$ & $<0.001$ \\
\hline No & 0 & 1 & - & 0 & 1 & - \\
\hline \multicolumn{7}{|l|}{$\begin{array}{l}\text { Current Cigarette } \\
\text { Smoker }\end{array}$} \\
\hline Yes & 0.96 & $2.61(2.43,2.80)$ & $<0.001$ & 0.70 & $2.02(1.87,2.19)$ & $<0.001$ \\
\hline No & 0 & 1 & - & 0 & 1 & - \\
\hline \multicolumn{7}{|l|}{ Being Bullied } \\
\hline Yes & 0.47 & $1.60(1.50,1.72)$ & $<0.001$ & 0.31 & $1.37(1.28,1.47)$ & $<0.001$ \\
\hline No & 0 & 1 & - & 0 & 1 & - \\
\hline
\end{tabular}

${ }^{*}$ Backward LR Multiple Logistic regression was applied. Multicollinearity and interaction were checked and not found. Classification Table (overall correctly classified percentage $=71.9 \%$. Area under ROC curve $=$ $61.8 \%$, with significant at $(\mathrm{p}<0.05)$ were accepted to check model fitness.

Family circumstances including parental separation and marital conflicts might affect adolescent psychology and contribute to truancy behaviour [30] [31], and [32] due to poor parent-child relationship. When the parents are not staying together, it is difficult due to lack of ability for single parent to monitor the adolescent's behaviour, thus leave them unsupervised and exposed to misbehaviour [33]. This was showed in our result, where adolescent who parents are 
not living together have higher prevalence and were 1.4 times likely to commit truancy compare to adolescent who their parent live together. In agreement with study done by [34], truancy behaviour increases when the adolescent lives with only one parent, either mother or father compare to adolescent who live with both parents.

Looking at risk factors, our findings are consistent with previous studies showing that illicit drug used, smoking and bully are high risk behaviour that contribute to truancy [13] [35] [36] and [37]. Health problem caused by smoking had led to high rate of school absenteeism and affect the academic performance among high school student in Indonesia [38]. [39] mention that both bullies and bullies' victim are more likely to play truant; bullies skipping school while victim absence from school due to fear. Psychological problem such as depression, anxiety, suicidal ideation and low self-esteem suffered by adolescent involve in bullying increase truant behaviour [5] [30] [40] and [41].

We have found several limitations for this study. School going adolescent's feedback was self-reported and subject to social desirability bias where the student might have tendency to answer the questionnaire either over reporting in good behaviour or under reporting on bad behaviour. Relationship of the factors stated in the study should be treated as an estimated association instead of causation due to the study design.

\section{Conclusion}

This study concluded that truancy can be the consequence of psycho-social factors influenced by family issues and psycho-behavioural factors due to curiosity in trying new thing among school going adolescent. Dynamic strategic approaches involving all parties concerned are essential to tackle school truant in order to prevent further negative effects of truancy, such as encouraging more parent's involvement in school activities, providing more creative, sport and recreational activities centers for the school going adolescent and improving on monitoring system in school to control truancy rate.

\section{Acknowledgements}

The authors would like to thank the Director General of Health Malaysia for his permission to publish this article.

\section{Conflicts of Interest}

The authors declare no conflicts of interest regarding the publication of this paper.

\section{References}

[1] Ocak, G., Ocak, İ. and Baysal, E.A. (2017) The Causes of Absenteeism of High School Students.

[2] Hocking, C. (2008) The Contributing Factors to Student Absenteeism/Truancy and 
the Effectiveness of Social Services and Interventions. Social Work Student Papers, 18.

[3] Shah, S.A., Abdullah, A., Aizuddin, A.N. and Rohaizat, M. (2012) Psycho-Behavioural Factors Contributing to Truancy among Malay Secondary School Students in Malaysia. ASEAN Journal of Psychiatry, 13, 128-137.

[4] Mijinyawa, S.I., Bakar, N. and Muhammad, A. (2015) Approaches to Solve the Problem of Truancy among Secondary School Students in Kuala Terengganu, Malaysia. IOSR Journal of Research \& Method in Education, 5, 63-70.

[5] Ishak, Z. and Low, S.F. (2013) Truancy among Malaysian Students: An Analysis Based on Ethnicity. Journal of Teaching and Education, 2, 331-338.

[6] Wijetunge, G.S. and Lakmini, W.D. (2011) School Refusal in Children and Adolescents. Sri Lanka Journal of Child Health, 40, 128-131. https://doi.org/10.4038/sljch.v40i3.3511

[7] Berg, I. (1992) Absence from School and Mental Health. The British Journal of Psychiatry: The Journal of Mental Science, 161, 154-166.

https://doi.org/10.1192/bjp.161.2.154

[8] Baleinakorodawa, L. (2009) Science AUDoS: Causes of Truancy from Mainstream Education for a Group of Pasifika Students Enrolled in Alternative Education. A Thesis Submitted to Auckland University of Technology in Partial Fulfillment of the Requirements for the Degree of Master of Arts in Social Sciences.

[9] Vaughn, M.G., Maynard, B.R., Salas-Wright, C.P., Perron, B.E. and Abdon, A. (2013) Prevalence and Correlates of Truancy in the US: Results from a National Sample. Journal of Adolescence, 36, 767-776. https://doi.org/10.1016/j.adolescence.2013.03.015

[10] Tobin, L. (2009) Education: Don't Just Walk Away: Truancy Rates Are up and Policies Don't Seem to Be Working. A New Study Suggests a Change of Track. The Guardian, 3.

[11] Chou, L.C., Ho, C.Y., Chen, C.Y. and Chen, W.J. (2006) Truancy and Illicit Drug Use among Adolescents Surveyed via Street Outreach. Addictive Behaviors, 31, 149-154.

[12] Mounteney, J., Haugland, S. and Skutle, A. (2010) Truancy, Alcohol Use and Alcohol-Related Problems in Secondary School Pupils in Norway. Health Education Research, 25, 945-954. https://doi.org/10.1093/her/cyq044

[13] Gastic, B. (2008) School Truancy and the Disciplinary Problems of Bullying Victims. Educational Review, 60, 391-404. https://doi.org/10.1080/00131910802393423

[14] Snyder, F.J., Acock, A.C., Vuchinich, S., Beets, M.W., Washburn, I.J. and Flay, B.R. (2013) Preventing Negative Behaviors among Elementary-School Students through Enhancing Students' Social-Emotional and Character Development. American Journal of Health Promotion: AJHP, 28, 50-58. https://doi.org/10.4278/ajhp.120419-QUAN-207.2

[15] WHO (2009) Global School-Based Student Health Survey (GSHS).

[16] Institutes for Public Health (2012) Kuala Lumpur: Ministry of Health Malaysia: The National Health and Morbidity Survey: Malaysia Global School-Based Student Health Survey 2012.

[17] (2011) SPSS I: IBM SPSS Statistics for Windows, Version 20.0. IBM Corp., New York.

[18] Yoep, N., Tupang, L., Jai, A.N., Kuay, L.K., Paiwai, F. and Nor, N.S.M. (2016) Prevalence of Truancy and Its Associated Factors among School-Going Malaysian 
Adolescents: Data from Global School-Based Health Survey 2012. Psychology, 7, 1053-1060.

[19] Hidayah, N.I., Hanafiah, M.S., Idris, M.N., Rosnah, S., Ibrahim, N.M.S. and Normah, C.D. (2003) Risk Behavior among Adolescents of a Rural Development Schemes in Peninsular Malaysia.

[20] World Health Organization (2015) W: Thailand 2015 Global School-Based Student Health Survey.

[21] Siziya, S., Muula, A.S. and Rudatsikira, E. (2007) Prevalence and Correlates of Truancy among Adolescents in Swaziland: Findings from the Global School-Based Health Survey. Child and Adolescent Psychiatry and Mental Health, 1, 15.

[22] Van Breda, M.J. (2006) Guidelines for Empowering Secondary School Educators, in Loco Parentis, in Addressing Truancy among Early Adolescent Learners. University of South Africa, Pretoria.

[23] Pengpid, S. and Peltzer, K. (2017) Prevalence, Demographic and Psychosocial Correlates for School Truancy among Students Aged 13-15 in the Association of Southeast Asian Nations (ASEAN) Member States. Journal of Child \& Adolescent Mental Health, 29, 197-203.

[24] Adika, L.O. (2016) Perceived Indices of Truancy among Selected Adolescents in Oyo Town: Implications for Behavioural Change. Journal of Education and Practice, 7, 42-45.

[25] Nik Jaafar, N.R., Tuti Iryani, M.D., Wan Salwina, W.I., Fairuz Nazri, A.R., Kamal, N.A., Prakash, R.J. and Shah, S.A. (2013) Externalizing and Internalizing Syndromes in Relation to School Truancy among Adolescents in High-Risk Urban Schools. Asia-Pacific Psychiatry, 5, 27-34.

[26] Finlay, K.A. (2005) Gender Differences among Truant Youth. Colorado Foundation for Families and Children National Ctr for School Engagement United States of America.

[27] Sanchez, M. (2012) Truancy and Chronic Absence in Redwood City. John W Gardner Center for Youth and Their Communities, Stanford.

[28] Glynn, T. and Berryman, M. (2005) Understanding and Responding to Students' Behaviour Difficulties. Learners with Special Needs, 10-20.

[29] Jones, T.R. (2009) Truancy: Review of Research Literature on School Avoidance Behavior and Promising Educational Re-Engagement Programs. Washington State University Division of Governmental Studies, Pullman.

[30] Moseki, M.M. (2009) The Nature of Truancy and the Life World of Truants in Secondary Schools. University of South Africa, Pretoria.

[31] Dembo, R., Briones-Robinson, R., Ungaro, R., Gulledge, L., Karas, L., Winters, K.C., Belenko, S. and Greenbaum, P.E. (2012) Emotional/Psychological and Related Problems among Truant Youths: An Exploratory Latent Class Analysis. Journal of Emotional and Behavioral Disorders, 20, 157-168.

[32] Monobe, R.J. and Baloyi, K. (2012) An Investigation into Some of the Major Causes of Truancy in the Venda Technical College in the Limpopo Province.

[33] Wilcox, P. (2003) An Ecological Approach to Understanding Youth Smoking Trajectories: Problems and Prospects. Addiction (Abingdon, England), 98, 57-77.

[34] Henry, K.L. (2007) Who's Skipping School: Characteristics of Truants in 8th and 10th Grade. The Journal of School Health, 77, 29-35.

[35] Assanangkornchai, S., Li, J., McNeil, E. and Saingam, D. (2018) Clusters of Alcohol 
and Drug Use and Other Health-Risk Behaviors among Thai Secondary School Students: A Latent Class Analysis. BMC Public Health, 18, 1272.

[36] McAra, L. (2004) Truancy, School Exclusion and Substance Misuse. The Edinburgh Study of Youth Transitions and Crime. Centre for Law and Society, the University of Edinburgh, Edinburgh, 4.

[37] Bill, R. (2010) Truancy: Causes, Effects, and Solutions. Education Masters, 107.

[38] Kusumawardani, N. and Suhardi, S. (2012) Behaviour Health Risk among Adolescents: A School-Based Health Survey with the Focus on Smoking in Male Adolescents Aged 12-15 in Depok, West Java, Indonesia.

[39] Dake, J.A., Price, J.H. and Telljohann, S.K. (2003) The Nature and Extent of Bullying at School. The Journal of School Health, 73, 173-180.

[40] Wet, C.D. (2005) The Voices of Victims and Witnesses of School Bullying. Koers Journal, 70, 705-725. https://doi.org/10.4102/koers.v70i4.289

[41] Malcolm, H., Wilson, V., Davidson, J. and Kirk, S. (2003) Absence from Schools: A Study of Its Causes and Effects in Seven LEAs. Department for Education and Skills (DFES). 